\title{
Mass Multiplication of Entomopathogenic Nematodes on in vitro Solid Media
}

\author{
K. Kranti K.V.V.S. ${ }^{1 *}$ and G. Narendra Kumar ${ }^{2}$ \\ ${ }^{1}$ AICRP Nematodes, LBS Building, ICAR-IARI, New Delhi-110012, India \\ ${ }^{2}$ National Plant Quarantine Station, Vasant Kunj Enclave, Near Kendriya Vidhalaya, Nangal \\ Dev Road, Rangpuri, New Delhi-37 Indial 10037
}

*Corresponding author

\begin{tabular}{|c|c|}
\hline & A B S T R A C T \\
\hline $\begin{array}{l}\text { Ke y w or d s } \\
\text { H. indica, Wout's } \\
\text { medium, } \\
\text { Entomopathogenic } \\
\text { nematodes, } S . \\
\text { abbasi }\end{array}$ & \multirow{3}{*}{$\begin{array}{l}\text { In this study, two Haryana local isolates of entomopathogenic nematodes (EPNs) namely } \\
\text { Steinernema abbasi and Heterorhabdus indica were mass multiplied on eight culture } \\
\text { media compromising of Wout's medium, Modified Wout's medium I, Modified Wout's } \\
\text { medium II, Modified Wout's medium III, Egg yolk medium I, Egg yolk medium II, } \\
\text { Modified egg yolk medium and Modified dog biscuit medium and harvested at two } \\
\text { different time intervals i.e. at } 30 \text { days and } 60 \text { days interval. Along with this, studies were } \\
\text { also conducted to know the effect of temperature i.e. at } 15^{\circ} \mathrm{C}, 20^{\circ} \mathrm{C} \text { and } 30{ }^{\circ} \mathrm{C} \text { on the } \\
\text { infective juvenile (IJ) yields. Of the eight media tested, S. abbasi and } \mathrm{H} \text {. indica both } \\
\text { multiplied maximum on modified dog biscuit medium. Wout's medium was second best in } \\
\text { IJs yield. Yield was maximum at } 30 \text { days and reduced drastically at } 60 \text { days. S. abbasi } \\
\text { yielded maximum at } 25^{\circ} \mathrm{C} \text { whereas } \mathrm{H} \text {. indica multiplied maximum at } 30^{\circ} \mathrm{C} \text {. None of the } \\
\text { species multiplied at } 15^{\circ} \mathrm{C} \text {. }\end{array}$} \\
\hline Article Info & \\
\hline $\begin{array}{l}\text { Accepted: } \\
\text { 24 June } 2018 \\
\text { Available Online: } \\
\text { 10 July } 2018\end{array}$ & \\
\hline
\end{tabular}

\section{Introduction}

The nematodes belonging to the genus Hetrorhabditis and Steinernema are by fame and name noted to be successful bio agents as they are used to control insect pests. These EPNs are symbiotically associated with bacteria of the genera Photorhabdus and Xenorhabdus that belongs to Enterobacteriaceae. EPNs have broad host range and exempted from the registration requirements in several countries (Kaya and Gaugler, 1993). The most important attribute is that they can be applied in conjugation with fertilizers, soil amendments and insecticides as upto 2-5 hours infective juveniles (IJs) are tolerant to their exposure (Rovesti et al., 1988; Rovesti and Desco, 1990). Tank mixed EPNs and pesticide combinations offer the cost effective alternative in Integrated Pest Management (IPM) as EPNs are safe and environmental friendly. For these aspects EPNs are required in bulk to apply in field level and they can be multiplied in laboratory or by commercial companies in vitro solid and liquid media. 
Based on the attractive attributes of entomopathogenic nematodes, the identified indigenous species are to be cultured in vivo or in vitro for large scale commercial production as well as for laboratory experimentation and field testing (Shapiro-Ilan et al., 2002). Since forties, the technology of in vitro mass rearing of EPNs has been developed (Glaser, 1940). At times EPNs are produced by variety of means by insect infection or on artificial media (axenic or monoxenic culture) in solid and liquid phase of fermentation. They are produced commercially by more than 10 countries in Asia, Europe and North America and to date more than 12 different species have reached a commercial development: $H$. bacteriophora Poinar 1976, H. indica Poinar et al., 1992, H. marelatus Liu and Berry 1966, H. megidis Poinar et al., 1987, H. zealandica Poinar 1990, S. carpocapsae, S. feltiae (Filipjev 1934) Wout's et al., 1982, S. glaseri, S. kushidai Mamiya 1988, S kraussei (Steiner, 1923) Travassos 1927, S. longicaudatum Shen and Wang 1992, S. riobrave and S. scapterisci Nguyun and Smart 1990 (Lacey et al., 2001).

For a biocontrol agent to be successful it should be amenable for mass production on a large scale, the ready availability of the organism in required quantity and at competitive cost makes them acceptable among entrepreneurs and farmers. Over the years many isolates of EPNs have been collected from Haryana soils. Though Haryana is a small state it represents diverse agroecological zones. The north eastern zone comprises of Shivalik hilly region and alluvial plains and the western zone consists mainly of alluvial plain. The major pests are rice root weevil, leaf folder, brown plant hopper, stem borer, sugarcane pyrilla, cotton boll worms, mustard aphids, cabbage diamond back moths, etc. Hence for the successful control of these pests the local isolates have to be collected, identified up to species level and their mass multiplication methods are to be standardized to use them in field against insect pests.

\section{Materials and Methods}

The culture of indigenous isolates of $S$. abbasi and $H$. indica were obtained from the Department of Nematology, CCSHAU, Hisar, Haryana. The cultures were multiplied on the last instar larvae of $G$. mellonella. Conical flasks, Petri plates, beakers, watch glasses were placed in hot air oven at $180{ }^{\circ} \mathrm{C}$ for $1 \mathrm{~h}$ before use. Forceps and needles were washed with absolute ethanol before use.

Composition of the eight media used (Hussaini et al., 2002)

a. Wout's medium: nutrient broth- $0.88 \mathrm{~g}$, yeast extract- $0.32 \mathrm{~g}$, soy flour- 14.4 $\mathrm{g}$,groundnut oil-10.4 $\mathrm{g}$ and distilled water$60 \mathrm{ml}$.

b. Modified Wout's medium I: nutrient broth- $0.88 \mathrm{~g}$, yeast extract- $0.32 \mathrm{~g}$, corn flour- $14.4 \mathrm{~g}$, groundnut oil-10.4 $\mathrm{g}$ and distilled water- $60 \mathrm{ml}$

c. Modified Wout's medium II: nutrient broth- $0.88 \mathrm{~g}$, yeast extract- $0.32 \mathrm{~g}$, soy flour- $14.4 \mathrm{~g}$, sesamum oil-10.4 $\mathrm{g}$ and distilled water- $60 \mathrm{ml}$

d. Modified Wout's medium III: nutrient broth- $0.88 \mathrm{~g}$, yeast extract- $0.32 \mathrm{~g}$, corn flour- $14.4 \mathrm{~g}$, sesamum oil-10.4 $\mathrm{g}$ and distilled water- $60 \mathrm{ml}$

e. Egg yolk medium I: egg yolk- 7.0 g, yeast extract- $2.0 \mathrm{~g}$, sodium chloride- $0.8 \mathrm{~g}$, groundnut oil- $15.0 \mathrm{~g}$ and distilled water$60 \mathrm{ml}$

f. Egg yolk medium II: egg yolk $-10.0 \mathrm{~g}$, yeast extract- $5.0 \mathrm{~g}$, sodium chloride- 0.8 $\mathrm{g}$, groundnut oil- $12.0 \mathrm{~g}$ and distilled water- $60 \mathrm{ml}$

g. Modified egg yolk medium: egg yolk- 7.0 $\mathrm{g}$, soy flour- $20.0 \mathrm{~g}$, yeast extract- $2.0 \mathrm{~g}$, sodium chloride- $0.8 \mathrm{~g}$, groundnut oil$15.0 \mathrm{~g}$ and distilled water- $60 \mathrm{ml}$

h. Modified dog biscuit medium: dog biscuit 
$20.0 \mathrm{~g}$, peptone- $0.5 \mathrm{~g}$, yeast extract $1.0 \mathrm{~g}$, beef extract $5.0 \mathrm{~g}$, groundnut oil- $7.0 \mathrm{~g}$ and distilled water- $100 \mathrm{ml}$

\section{Preparation of media for the multiplication of EPNs}

In each medium the ingredients were weighed according to the requirement and mixed in distilled water. The medium was gently heated and stirred uniformly.

In one basin sponge material (polyether polyurethane foam) which was cut into small pieces of $1 \times 1 \mathrm{~cm}^{3}$ was taken and washed thoroughly with distilled water 2 to 3 times. These were dried at room temperature. The medium was poured into the basin containing the sponge and mixed thoroughly, so that it was coated uniformly onto foam pieces $(1.5 \mathrm{~g}$ foam chips, 8 to $9 \mathrm{~g}$ medium w/w).

The conical flasks (250 $\mathrm{ml}$ capacity) were filled with 8 to 10 media coated sponges. The mouth of the flask was cleaned to remove the adhered medium and plugged tightly with non-absorbent cotton. These flasks were autoclaved at $121.6{ }^{\circ} \mathrm{C}$ for 20 to 30 minutes. After autoclaving, the flasks were allowed to cool before use.

\section{Preparation of nutrient agar and nutrient broth}

For the preparation of nutrient agar, the ingredients (peptone- $5.0 \mathrm{~g}, \mathrm{NaCl}-5.0 \mathrm{~g}$, beef extract- $3.0 \mathrm{~g}$, yeast extract- $2 \mathrm{~g}$, agar- $20 \mathrm{~g}$ ) were weighed and mixed in 1 litre distilled water, gently heated by stirring uniformly.

The medium was poured in conical flasks (250 $\mathrm{ml}$ capacity) plugged with cotton and autoclaved at $121.6{ }^{\circ} \mathrm{C}$ for 15 to $20 \mathrm{~min}$. Nutrient broth also prepared as above separately in which agar was not added.

\section{Isolation and preparation of symbiotic bacterial cultures}

The isolation of the symbiotic bacteria from the haemolymph of Galleria mellonella Linnaeus (greater wax moth) larvae was done following the method of Kaya and Stock 1997. Under a laminar flow sterile bench, late instar larvae of G. mellonella were placed in a Petri dish with moist filter paper and inoculated with IJs separately for each nematode species (100 IJs per larva). The cadavers so obtained were surface sterilized with $1.0 \%(\mathrm{w} / \mathrm{v})$ sodium hypochlorite solution and rinsed three times with sterilized water.

The cadaver was dipped in absolute ethanol, ignited and immediately plunged into sterile water. Using the sterile injection needles the cadaver was carefully opened from the ventral side. Then using a sterile inoculation loop, the haemolymph of the cadaver was slightly touched and transferred to the nutrient agar plates by streaking in a zig-zag manner near the burner. The Petri plates were then properly labeled, put in polythene cover and kept at 25 to $28 \pm 1^{\circ} \mathrm{C}$ for $48 \mathrm{~h}$ in an BOD incubator.

\section{Multiplication of symbiotic bacteria}

In the laminar flow chamber, the single colonies of the bacterium in the nutrient agar were gently touched with sterile inoculating loop and transferred to the nutrient broth in flasks. The flasks inoculated with the bacterium, were wrapped with black paper, kept on the mechanical shaker and continuously stirred at room temperature for 24 to $48 \mathrm{~h}$. After $48 \mathrm{~h}$ bacterium culture so obtained was inoculated to the media in flasks at $0.5 \mathrm{ml}$ per flask, kept in dark at 25 to $28 \pm 1^{\circ} \mathrm{C}$ in a BOD incubator.

\section{Surface sterilization of IJs}

The IJs were collected in $100 \mathrm{ml}$ of clean sterile distilled water. The IJs were surface 
sterilised by adding $1 \mathrm{ml} \quad 0.25 \% \quad(\mathrm{w} / \mathrm{v})$ Hyamine (methylbenzethonium chloride) to the suspension and washed with sterile water 2 to 3 times in the laminar air flow chamber. With a sterile micropipette, most of the supernatant was removed without disturbing the IJs at the bottom of the tube. Each step was started with enough IJs to compensate for some loss during the process. At the final step the surface sterilized IJs which were collected in a beaker with sterile distilled water. The suspension was adjusted so that $1 \mathrm{ml}$ contained approximately 2000 IJs.

\section{Inoculation of IJs into the medium and incubation of media}

The nematodes were inoculated in the flasks @ $2000 \mathrm{IJs}$ per flask $(250 \mathrm{ml})$ under aseptic conditions. The cotton plugged flasks were wrapped with paper to ensure dark conditions and incubated at $25 \pm 1^{\circ} \mathrm{C}$ for 30 and 60 days. The flasks were checked for contamination on every alternate day. Each treatment was replicated four times. IJs of $S$. abbasi were inoculated in the flasks containing Xenorhabdus bacterium and IJs of $H$. indica were inoculated into flasks containing Photorhabdus bacterium.

\section{Harvesting of IJs}

After the incubation for 30 and 60 days at $25 \pm 1{ }^{\circ} \mathrm{C}$, the IJs were extracted from the different media by pouring out the coated sponge media on 400 mesh sieve placed in the water filled basin for $1 \mathrm{~h}$. The IJs were collected from the basin and concentrated in a beaker. The nematodes were counted under the microscope by the dilution method and the final observation on yield (number of IJs) in each flask was recorded.

\section{Statistical analysis}

The data were analysed statistically by using Completely Randomized Design (CRD) following 'OP Stat' available at CCS HAU, Hisar, website.

\section{Results and Discussion}

A steinernematid, $S$. abbasi and a heterorhabditid, $H$. indica were inoculated on eight different media (composition as given in materials and methods) to select the most suitable medium for multiplication. The number of IJs recorded after 30 and 60 days of inoculation are put together in Table 1. The data revealed that both the species multiplied maximum on modified modified dog biscuit medium (71,56,071 and 10,21,634 IJs per 250 $\mathrm{ml}$ flask of $S$. abbasi and H. indica (Fig. 2a, 3a), respectively). S. abbasi yield was significantly more than $H$. indica in all the media except Wout's medium where $H$. indica IJs recovered were more $(6,99,100$ IJs per 250 ml flask) compared to $S$. abbasi $(58,333$ IJs per $250 \mathrm{ml}$ flask). In all other media, S. abbasi multiplied better than $H$. indica. Out of eight media tested, four viz., modified Wout's medium II, egg yolk medium I, II and modified egg yolk medium were unsuitable for multiplication, since there were no IJs recovery of the two species in these media except in egg yolk medium I where a very low yield of $S$. abbasi (2,664 IJs per $250 \mathrm{ml}$ flask) was obtained.

The order of suitability of the media for the multiplication of $S$. abbasi was modified dog biscuit medium (71 lakh IJs), modified Wout's medium III (2.07 lakh IJs), modified Wout's medium I (77 thousand IJs), Wout's medium (58 thousand IJs) and egg yolk medium I (2.6 thousand IJs) whereas for $H$. indica modified dog biscuit medium (10 lakh IJs) was followed by Wout's medium (6.99 lakh IJs), modified Wout's medium III (31.7 thousand IJs) and modified Wout's medium I (15.9 thousand IJs).

The recovery of IJs was reduced after 60 days so much so that there were $36 \%$ less IJs in $S$. 
abbasi and $65 \%$ less in $H$. indica from modified dog biscuit medium. In all other media too, there was $30-70 \%$ reduction in IJs yield in both the nematode species.

Of the eight media used, Wout's medium and modified dog biscuit medium were selected to study the effect of temperature on IJs yield of both the nematode species. At $15^{\circ} \mathrm{C}, \mathrm{S}$. abbasi gave similar yield in both the media where as $H$. indica did not multiply in any of the two media (Fig. 1A, B, 4 and 5). S. abbasi multiplied maximum in modified dog biscuit medium at $25^{\circ} \mathrm{C}$ followed by Wout's medium at the same temperature. S. abbasi did not multiplied in Wout's medium at $30^{\circ} \mathrm{C}$ while in modified dog biscuit medium the yield was low compared to $25^{\circ} \mathrm{C}$. $H$. indica in comparison to $S$. abbasi multiplied better in both the media at $30^{\circ} \mathrm{C}$ than at $25^{\circ} \mathrm{C}$ and more so in modified dog biscuit medium.

Table.1 Number of infective juveniles produced on different media at two time intervals (Mean of four replications)

\begin{tabular}{|c|c|c|c|c|}
\hline \multirow{2}{*}{$\begin{array}{l}\text { Nematode species } \\
\text { MEDIA }\end{array}$} & \multicolumn{2}{|c|}{ Steinernema abbasi } & \multicolumn{2}{|c|}{ Heterorhabditis indica } \\
\hline & 30 DAYS & 60 DAYS & 30 DAYS & 60 DAYS \\
\hline Wout's medium & $\begin{array}{l}58,333 \\
(4.77)\end{array}$ & $\begin{array}{l}10,289 \\
(4.01)\end{array}$ & $\begin{array}{l}6,99,100 \\
(5.84)\end{array}$ & $\begin{array}{l}1,29,450 \\
(5.10)\end{array}$ \\
\hline Modified Wout's medium I & $\begin{array}{l}77,389 \\
(4.89)\end{array}$ & $\begin{array}{l}24,375 \\
(4.39)\end{array}$ & $\begin{array}{l}15,949 \\
(4.20)\end{array}$ & $\begin{array}{l}7,225 \\
(3.85)\end{array}$ \\
\hline Modified Wout's medium II & - & - & - & - \\
\hline Modified Wout's medium III & $\begin{array}{l}2,07,455 \\
(5.27)\end{array}$ & $\begin{array}{l}52,408 \\
(4.57)\end{array}$ & $\begin{array}{l}31,770 \\
(4.50)\end{array}$ & $\begin{array}{l}24,330 \\
(4.37)\end{array}$ \\
\hline Egg yolk medium I & $\begin{array}{l}2664 \\
(3.41)\end{array}$ & - & - & - \\
\hline Egg yolk medium II & - & - & - & - \\
\hline Modified Egg yolk medium & - & - & - & - \\
\hline Modified dog biscuit medium & $\begin{array}{l}71,56,071 \\
(6.85)\end{array}$ & $\begin{array}{l}45,90,469 \\
(6.66)\end{array}$ & $\begin{array}{l}10,21,634 \\
(6.00)\end{array}$ & $\begin{array}{l}2,97,646 \\
(5.47)\end{array}$ \\
\hline $\mathrm{CD}$ at $5 \%$ & $(0.18)$ & $(0.33)$ & $(0.06)$ & $(0.17)$ \\
\hline
\end{tabular}

Figures in parentheses are log transformed values 
Fig.1 Multiplication of (A) Steinernema abbasi \& (B) Heterorhabditis indica on modified dog biscuit medium and Wout's medium at different temperatures. (Mean of four replications)
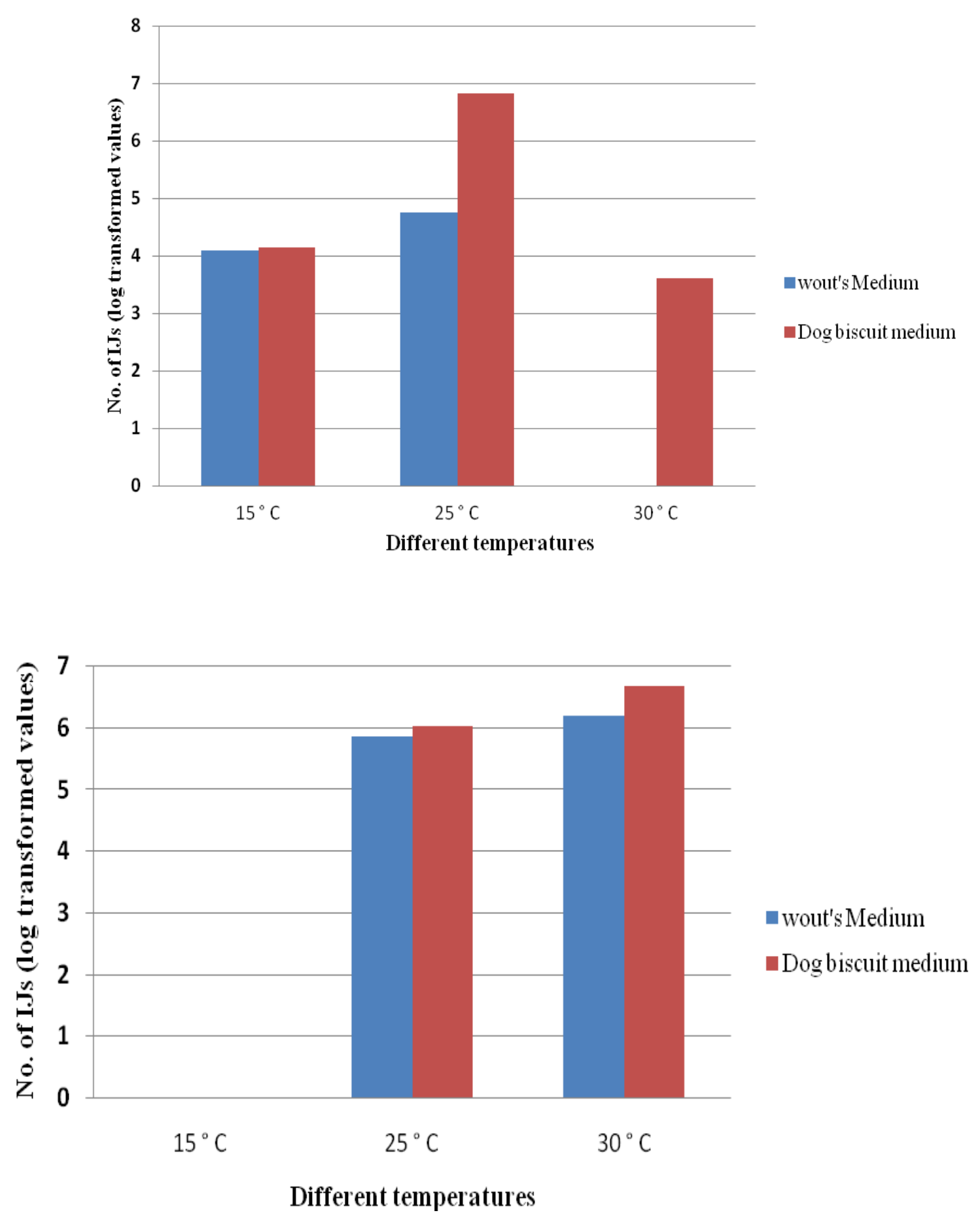
Fig.2 Multiplication of Steinernema abbasi after 30 days of nematode inoculation; a) Modified dog biscuit medium, b) Modified Wout's medium I, c) Egg yolk medium I, d) Modified Wout's medium III e) Multiplication of Steinernema abbasi on modified dog biscuit medium after 60 days of inoculation
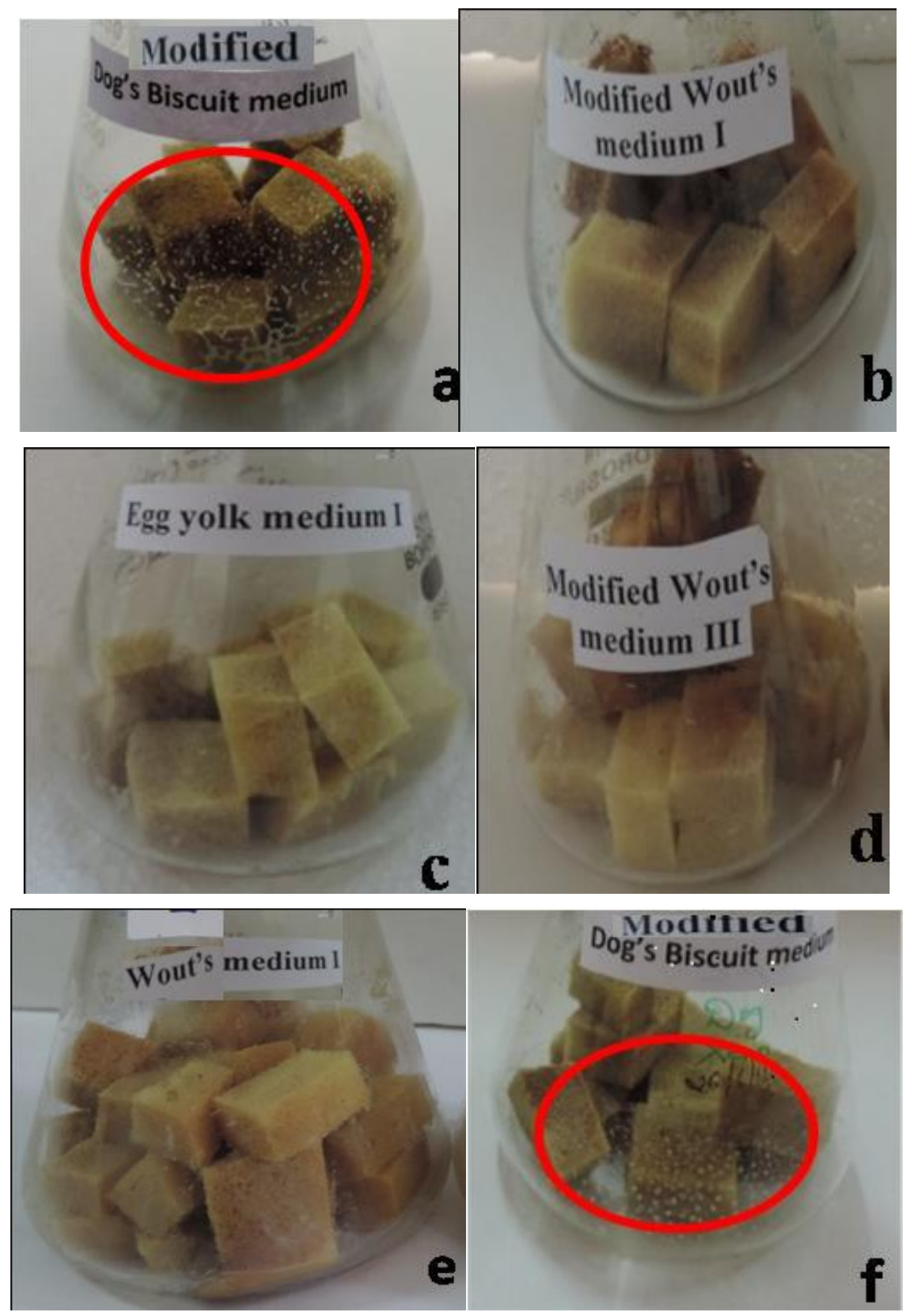
Fig.3 Multiplication of Heterorhabditis indica after 30 days of nematode inoculation; a)

Modified dog biscuit medium, b) Modified Wout's medium I, c) Modified Wout's medium III,

d) Wout's medium e) Multiplication of Heterorhabditis indica after 60 days of nematode inoculation on modified dog biscuit medium

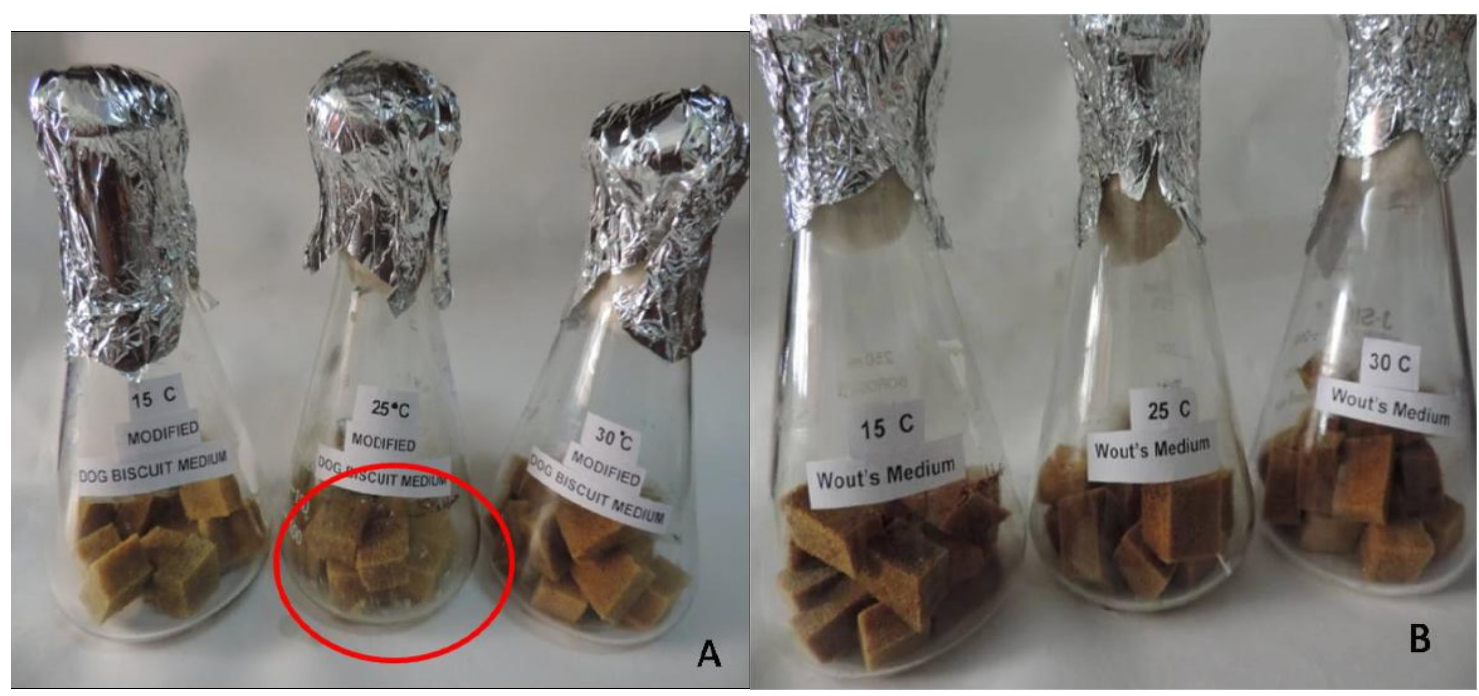

Fig.5 Multiplication of Heterorhabditis indica on A) Modified dog biscuit medium and B) Wout's media at three different temperatures

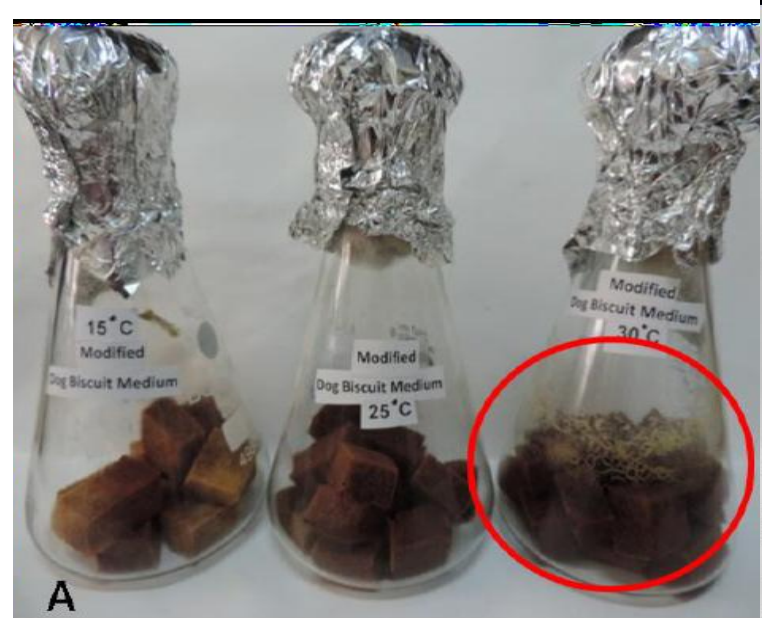

Entomopathogenic nematode's potential as efficient biocontrol agents can only be assessed by field applications for which large number of infective juveniles (IJs) are required. For small scale experimentation, IJs can be multiplied on natural host or alternate host, G. melonella being the most preferred for in vivo culturing of the majority of the

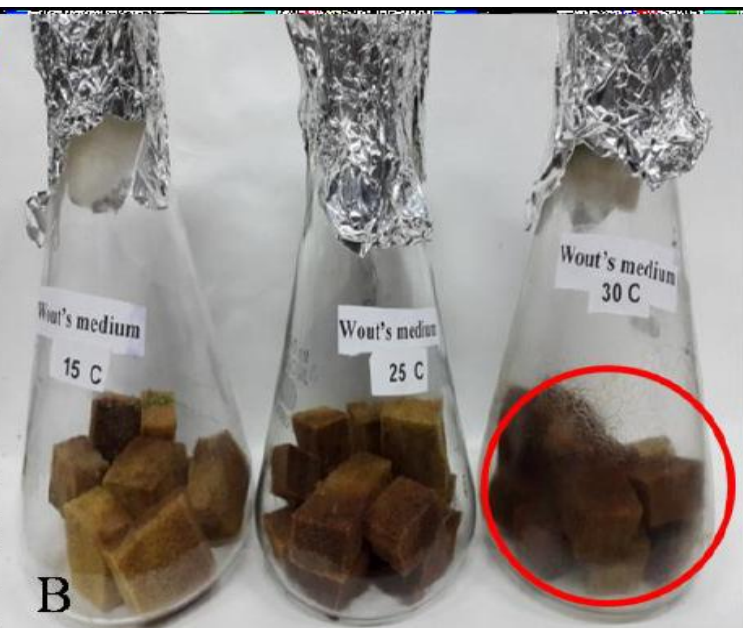

species. This method is not cost effective and involves a lot of labor. So, efforts in the direction to culture these in vitro were initiated by Glaser as early as 1940 on a solid medium axenically. Soon, it was established that inoculation of natural symbiotic bacterium to the medium before nematode inoculation increased the yields considerably 
(Poinar and Thomas, 1966). Also the primary form of bacterial symbiont is better suited for EPNs (particularly Heterorhabditis) than secondary form. Wout's 1981 and Bedding 1981 used plant protein origin and animal protein origin media for culturing EPNs in vitro. To increase the surface area polyether polyurethane sponge was used. Plant protein origin media are preferred since animal protein origin media smell awfully.

Keeping all the conditions in view, five different media of plant protein origin viz. Wout's, Wout's I, Wout's II, Wout's III and modified dog biscuit (purely of vegetative origin) media and those of animal protein origin (Egg yolk I, Egg yolk II and Egg yolk III) were used to culture indigenous isolates of $S$. abbasi and $H$. indica to select the most suitable medium. In our study animal protein media (all Egg yolk media) did not yield any progeny. Modified dog biscuit medium (consisting of wheat flour, oats, corn, rice and vegetables supplemented with herbal liver tonic) yielded maximum yielded maximum in both the species, $S$. abbasi and $H$. indica. The yield was higher in Steinernema compared to Heterorhabditis though no particular reason could be worked out yet the possibility of changing primary form of bacterium to secondary form can be one of the reasons. Dog biscuits were successfully as early as 1965 by House et al., in Canada to mass multiply $S$. carpocapsae (DD 136 strain). Similar results were also obtained by Hara et al., (1981) and Kondo and Ishibashi in 1985 and 1991. In all these studies dog biscuit or dog food medium were of animal protein origin whereas in the present study dog biscuits were of plant protein origin.

Hussaini et al., (2002) reported that $H$. indica (PDBC EN6.7) multiplied well on Wout's medium and modified Wout's medium containing soy flour and groundnut oil in various proportions. However in our studies
$H$. indica yielded more in medium with soy flour and groundnut oil whereas $S$. abbasi preferred corn flour and sesamum oil medium. Ogura and Haraguchi (1993) reported that in general plant protein origin media supported low multiplication compared to animal protein origin which is in contrast to our observations where plant protein based media yielded more. Also the report of Pervez and Ali (2010) that S. masoodi, S. mushtaqi and $S$. seemae multiply more on egg yolk medium is not consumerate with our studies where both the species did not multiply on this medium or its modifications thereof. Our study also not gained support from Prabhu et al., (2006) who reported more multiplication on animal protein medium than plant protein medium. The variation can be due to different species/ isolate used since EPN species behave differently in different environments. Hence, there is a need to standardize the medium and the culture conditions for every new isolate to obtain maximum yield. The cultures yielded maximum after 30 days which decreased drastically at 60 days. The plausible reason for this can be the depletion of the food material and/or accumulation of toxic metabolites. Hence, the cultures are to be subcultured every month to maintain their viability and growth potential.

The entomopathogenic nematodes isolated from temperate areas are adapted to low temperature conditions whereas those isolated from tropical or sub tropical areas can tolerate warmer conditions. There is a variation in this temperature tolerance in different species of two genera and a set of temperature conditions are required for their growth and multiplication. In the present investigations, both the species were isolated from the Haryana soils even then there was variation in their temperature requirement. S. abbasi yielded more at $25^{\circ} \mathrm{C}$ whereas $H$. indica multiplied maximum at $30^{\circ} \mathrm{C}$. In $H$. indica $\mathrm{IJs}$, second stage cuticle is retained in most of the 
specimens which perhaps renders it more tolerant to environmental conditions. Similar results were obtained by Yamanaka et al., (2000) who reported $25^{\circ} \mathrm{C}$ as temperature suitable for multiplication of $S$. glaseri which did not survive at and above $30^{\circ} \mathrm{C}$. Han et al., (1993) too observed that normal temperature range for IJ production of $S$. carpocapsae was $19-27^{\circ} \mathrm{C}$ and below $15^{\circ} \mathrm{C}$ and above $31^{\circ} \mathrm{C}$ no offspring produced due to increase in mortality. $H$. bacteriophora multiplied maximum at $28 \pm 2^{\circ} \mathrm{C}$ (Floyd et al., 2012). In Pakistan, Salma and Shahina (2012) observed that all the EPN strains tested multiplied at $32 \pm 2^{\circ} \mathrm{C}$ except $S$. feltiae which reproduces better at $20^{\circ} \mathrm{C}$ since this is a cold tolerant species.

\section{References}

Filipjev, I. N., 1934. The classification of the freeliving nematodes and their relations to parasitic nematodes. Smithsonian Miscellaneous Collection.89, 1-63.

Floyd, L. Inma, I. I. I. and Singh, S., 2012. Mass production of beneficial nematode Heterorhabditis bacteriophora and its bacterial symbiont Photorhabdus luminescens. Indian Journal of Microbiology.52, 316- 324.

Glaser, R. W., 1940. Continued culture of a nematode parasite in a Japanese beetle. Journal of Experimental Zoology.84, 1-12.

Han, R., Cao, L. and Liu, X., 1993. Effects of inoculum size, temperature and time on in vitro production of Steinernema carpocapsae Agriotos. Nematologica.39, 366-375.

Hara, A. H., Lindegren, and Kaya, H. K., 1981. Monoxenic mass production of the entomopathogenic nematode, Neoaplectana carpocapsae Weiser on dog food-agar medium. U.S. Department of Agriculture. $\mathrm{W}-16,18$.

House, H. L., Welch, H. E. and Cleugh, T. R., 1965. Food medium prepared of dog biscuit for the mass production of the nematode DD-136 (Nematoda: Steinernematidae). Nature. 206, 847.
Hussaini, S. S., Singh, S. P., Parthasarathy, R. and Shakeela, V., 2002. In vitro production of entomopathogenic nematodes in different artificial media. Indian Journal of Nematology.32, 44- 46.

Kaya, H. K. and Stock, S. P., 1997. Techniques in insect nematology. (ed. L. Lacey), pp. 281324. Academic Press, San Diego, California.

Kaya, H. K. and Gaugler, R., 1993. Entomopathogenic nematodes. Ann. Rev. Entomol.38181-206

Kondo, E. and Ishibashi, N., 1991. Dependency of three Steinernematid nematodes on their symbiotic bacteria for growth and propagation. Japanese Journal of Nematology. 21, 11- 17.

Kondo, E., Honda, S. and Ishibashi, N., 1985. Growth and propogation of entomogenous nematodes, Steinernema spp. on several kinds of media prepared from chicken liver and intestine. Japanese Journal of Nematology. 15, 1-10.

Lacey, L. A., Frutos, R., Kaya, H. K. and Vail, P., 2001. Insect pathogens as biological control agents: do they have a future? Biological Control.21, 230-248.

Liu, J. and Berry, R. E., 1996.Heterorhabditis marelatus n. sp. (Rhabditida: Heterorhabditidae) from Oregon. Journal of Invertebrate Pathology.67, 48-54.

Mamiya, Y., 1988.Steinernema kushidai n. sp. (Nematoda: Steinernematidae) associated with scarabaeid beetle larvae from Shizuoca, Japan. Applied Entomology and Zoology.23, 313- 320.

Nguyen, K. B. and Smart, Jr G. C., 1990.Steinernema scapterisci n. $\mathrm{sp}$. (Steinernematidae: Nematoda). Journal of Nematology.22, 187- 199.

Ogura, N. and Haraguchi, N., 1993. Xenic culture of Steinernema kushidai (Nematoda: Steinernematidae) on artificial media. Japanese Journal of Nematology.39, 266273.

Pervez, R. and Ali, S. S., 2010.In vitro mass production of entomopathogenic nematodes in different artificial media. Current Nematology.21, 9- 12.

Poinar G. O. Jr. and Thomas, G. M., 1966. Significance of Achromobacter nematophilus (Achromobacteriaceae: 
Eubacteriales) in the development of the nematode, DD- 136 (Neoaplectana sp. Steinernematidae). Parasitology. 56, 385390.

Poinar, G. O. Jr, Karunakar, G. and David, H., 1992.Heterorhabditis indicus (Rhabditida: Nematoda) from India: separation of Heterorhabditis spp. by infective juveniles. Fundamentals of Applied Nematology.15, 467-472.

Poinar, G. O. Jr., 1976. Description and biology of a new insect parasitic rhabditoid, Heterorhabditis bacteriophora n. gen., n. sp. (Rhabditida; Heterorhabditidae n. fam.).Nematologica.21, 463- 470.

Poinar, G. O. Jr., 1990. Taxonomy and biology of Steinernematidae and Heterorhabditidae. Entomopathogenic nematodes in biological control (eds R. Gaugler and H. K. Kaya), pp. 23 - 61. CRC Press, Boca Raton, Florida, U.S.A.

Poinar, G. O., Jr., Jackson, T. and Klein, M., 1987. Heterorhabditis megidis sp. $\mathrm{n}$. (Heterorhabditidae: Rhabditida) parasitic in the Japanese beetle, Popillia japonica (Scarabaeidae: Coleoptera), in Ohio. Proceedings of the Helminthological Society of Washington.54, 53-59.

Prabhu, S., Rajendran, G. and Subramanian, S. 2006.In vitro mass production technology for the entomopathogenic nematode, Steinernema glaseri. Indian Journal of Nematology.36, 142- 144.

Rovesti L., 1989. Response of Steinernema spp. and Heterorhabditis spp. to chemical pesticides. In: Proceeding of the International Conference Biopesticides. Theory and Practice: 186-190

Rovesti L., Deseö K.V., 1990. Compatibility of chemical pesticides with entomopathogenic nematodes. Steinernema carpocapsae Weiser and S. feltiae Filipjev (Nematoda: Steinernematidae). Nematology.36, 237-245.

Salma, J and Shahina, F., 2012. Mass production of eight Pakistani strains of EPNs (Steinernematidae and Heterorhabditidae). Pakistan Journal of Nematology. 30, 1- 20.

Shapiro-Ilan, D. I., Gouge, D. H. and Koppenhofer, A. M., 2002. Factors Affecting Commercial Success: Case Studies in Cotton, Turf and Citrus. (ed. R. Gaugler), pp. 335. CABI Publication, CAB International, Wallingford, Oxon, UK.

Shen, C. P. and Wang, G. H., 1992. Description and studies of an entomopathogenic nematode: Steinernema longicaudatum sp. nov. In: Proceedings of the first national academy symposium of young and middle aged science and technology workers on plant protection, Beijing, China. Chinese Science and Technology Press, pp. 230- 223.

Steiner, G., 1923Neoplectana kraussei n. sp. Steiner in der Blattwespe Lyda sp.parasitierende Nematodenform Zentralblatt fur. Bakteriologie Zweite Abteilun.59, 14-18.

Travassos, L., 1927 Sobre ogenera Oxysomatium. Boletim. Biologico.5, 20-21.

Wouts, W. M., Mracek, Z., Gerdin, S. and Bedding, R. A., 1982. Neoaplectana Steiner, 1929, a junior synonym of Steinernema Travassos, 1927 (Nematoda: Rhabditida). Systematic Parasitology.4, 147 - 154.

Yamanaka, S., Tanabe, H. and Takeuchi, K., 2000. Influence of temperature on growth and propagation of Steinernema glaseri (Nematoda: Steinernematidae). Japanese Journal of Nematology.30, 47- 50.

\section{How to cite this article:}

K. Kranti K.V.V.S. and Narendra Kumar, G. 2018. Mass Multiplication of Entomopathogenic Nematodes on in vitro Solid Media. Int.J.Curr.Microbiol.App.Sci. 7(07): 3282-3292. doi: https://doi.org/10.20546/ijcmas.2018.707.382 